\title{
SYMPOSIUM INTERNATIONAL GALILEO 2001 TENERIFE, FEBRUARY 19-23, 2001
}

The Fundación Canaria Orotava de Historia de la Ciencia is organizing an international conference ("Symposium Galileo 2001 ) in Tenerife (Canary IslandsSpain), from February 19-23, 2001.

1. The subject matter of the conference will be organized in three divisions :

- Galileo's science;

- Galileo and the Church;

- the century of Galileo.

Under the first heading, as well as the contributions of Galileo to specific fields of newly emerging science : mechanics, the laws of motion, cosmology, etc., the conference will bring out his development of a self-contained branch of knowledge, with its contents and techniques, and its relationship to traditional philosophy at the end of the $x \mathrm{II}^{\text {th }}$ century.

Independently of the contents of his work, it was just this development of a selfcontained new form of understanding the world which led inevitably to his conflict with the Church, at first via the disguised sentence of 1616 , and later with the definitive sentence of 1633 . We should stress that Galileo's work, from 1610 until his death, should be judged against the background of this serious major conflict.

Thirdly we will consider the cultural, ideological and institutional context in which Galileo developed his ideas (the University, the Court, the Academies), and the qualities of the patronage and financial support for science at that time. We will then consider Galileo's legacy ; the role of the Galilean School in Italy, the rise in Italy and in other European countries of new intellectual figures, often outside the universities. We will look at the development of the new scientific spirit, whose guiding light was Galileo, characterized by the introduction of mathematics in the study of nature and of the universe.

2. The Scientific Organizing Committee has the following members:

Paolo Galluzzi (Istituto e Museo di Storia della Scienza, Firenze),

Maurizio Torrini (Università di Napoli),

Enrico Giusti (Università di Firenze),

Maurice Clavelin (Université de Paris-Sorbonne),

Michel Lerner (Observatoire de Paris),

Revue de synthèse : $4^{e}$ S. no 4 , oct.déc. 1999, p. 687-688. 
Isabelle Pantin (Université de Nanterre),

William R. Shea. (Académie Internationale d'Histoire des Sciences), Maurice A. Finocchiaro (University of Nevada, Las Vegas),

Thomas B. Settle (Polytechnic University, New York),

Ronald Naylor (Independent scholar),

Jürgen Renn (Max-Planck-Institut für Wissenschaftsgeschichte, Berlin),

Carlos Solís (Universidad Nacional de Educación a Distancia, Madrid),

Antonio Beltrán (Universidad Autónoma de Barcelona),

José L. Montesinos (Fundación Canaria Orotava de Historia de la Ciencia).

3. The members of the Organizing Committee are:

Javier Echevería (Consejo Superior de Investigaciones Científicas, Madrid),

Romano Gatto (Università della Basilicata),

Massimo Bucciantini (Università di Siena),

Egidio Festa (Centre Alexandre-Koyré CNRS-EHESS, Paris),

Amparo Gómez (Universidad de La Laguna),

Jesús Sánchez (Universidad de La Laguna),

John Beckman (Instituto Astrofísico de Canarias),

Carlos Martín (Fundación Canaria Orotava de Historia de la Ciencia),

Carlos Mederos (Fundación Canaria Orotava de Historia de la Ciencia),

Miguel Hernández (Fundación Canaria Orotava de Historia de la Ciencia),

José L. Montesinos (Fundación Canaria Orotava de Historia de la Ciencia).

Italian.

4. The official languages of the Conference are Spanish, English, French, and

Fundación Canaria Orotava de Historia de la Ciencia

C) Calvario $n^{\circ} 17,38300$ La Orotava, Tenerife

Tfno : 922322862, Fax : 922322513, E-Mail : s-orotava@redestb.es 